\title{
PEMANFAATAN TAMAN BACAAN MASYARAKAT (TBM) DALAM MENINGKATKAN MINAT BACA REMAJA (Studi Kasus di TBM Gunung Ilmu)
}

\author{
Dini Susanti ${ }^{1}$, Santi $^{2}$ \\ 1,2 IKIP SILIWANGI \\ 1dinisusanti1@gmail.com, 2santiajja54@gmail.com
}

\begin{abstract}
ABSTRAK
Saat ini kurangnya kegemaran membaca di kalangan remaja terjadi karena remaja telah diberikan informasi secara instan yang biasa diperoleh dari siaran TV dan media elektronik lainnya. Di samping itu, para remaja saat ini menganggap membaca merupakan hal yang membosankan. Padahal dengan membaca kita bisa memperluas kemampuan pengetahuan kita, yang membuat kita untuk lebih tanggap terhadap lingkungan sekitar kita. Tujuan dari dilakukannya penelitian ini, yaitu : (1) Untuk mengetahui sampai mana pengetahuan remaja tentang keberadaan TBM. (2) Untuk mendeskripsikan minat dan pemanfaatan TBM oleh remaja sebagai pusat media pembelajaran. (3) Untuk mengetahui kendala-kendala yang dihadapi oleh para remaja hingga saat ini. Penelitian ini menggunakan pendekatan kualitatif dengan metode deskriptif, untuk instrumen yang digunakan yaitu observasi, wawancara, dan studi kepustakaan. Sasaran atau sumber data yang dipakai dalam penelitian ini adalah Pengelola berjumlah 1 orang, Pemilik TBM Gunung Ilmu berjumlah 1 orang, serta pengunjung remaja dari TBM Gunung Ilmu berjumlah 3 orang. Kendala yang sering dihadapi oleh remaja salah satunya yaitu masih optimal nya promosi yang dilakukan pengelola dalam mengajak mereka agar mau datang dan mengikuti kegiatan yang ada di TBM.
\end{abstract}

Kata Kunci : Remaja, Minat Baca, Taman Bacaan Masyarakat (TBM)

\section{PENDAHULUAN}

Pendidikan pada dasarnya, sebagaimana di dalam pembukaan UUD 1945 alinea ke-4, pendidikan bertujuan untuk mencerdaskan kehidupan bangsa. Hal ini, senada juga dengan UU tentang Sistem Pendidikan Nasional (SISDIKNAS) dalam UU Nomor 20 Tahun 2003 pasal 1(1), yang menyebutkan bahwa "Pendidikan adalah usaha sadar dan terencana untuk mewujudkan suasana belajar dan proses pembelajaran agar peserta didik secara aktif mengembangkan potensi dirinya untuk memiliki kekuatan spiritual keagamaan, pengendalian diri, kepribadian, kecerdasan, akhlak mulia, serta keterampilan yang diperlukan oleh dirinya, masyarakat, bangsa, dan negara".

Sehubungan dengan hal di atas, terdapat tiga jalur atau satuan pendidikan, yaitu Pendidikan Informal, Pendidikan non formal, dan Pendidikan Formal. Hal ini, merupakan tri pusat pendidikan, yang menjadi salah satu media pembelajaran yang relatif strategis, yaitu Pembelajaran melalui Pendidikan non formal yang dipandang bisa berkontribusi terhadap peningkatan mutu Sumber Daya Manusia (SDM), melalui berbagai pendidikan 
keterampilan. Salah satu sasaran strategis adalah upaya dalam meningkatkan minat membaca bangsa indonesia.

Menurut data UNESCO, minat baca masyarakat Indonesia sangat memprihatinkan, hanya $0,001 \%$. Artinya dari 1000 orang Indonesia, hanya 1 orang yang rajin membaca, sedangkan riset yang bertajuk "Most Littered Nation In The World" yang dilakukan oleh Central Connecticut State University pada Maret 2016 di New Britain, Conn, Amerika Serikat, menyebutkan indonesia berada di tempat yang cukup memprihatinkan yaitu menduduki peringkat ke-60 dari 61 negara mengenai minat membaca. Sedangkan dari segi penilaian infrastruktur untuk mendukung membaca peringkat Indonesia berada di atas negara-negara eropa, yaitu di urutan ke 34. (Budimanali : 2019).

Minat akan membaca di kalangan remaja saat ini masih relatif rendah, karena para remaja masih belum menjadikan membaca sebagai budaya dan kebutuhan hidup mereka. Padahal, banyak orang yang bilang buku merupakan gudangnya ilmu pengetahuan, di mana kita mendapatkan wawasan yang luas dan informasi baik dari dalam negeri maupun dari luar negeri. Meski informasi yang kita dapatkan tidak secara langsung. Menurut pemerintah, orang yang membiasakan diri untuk membaca, nantinya dapat bersaing di pasar global di masa depan.

Saat ini yang memprihatinkan adalah perilaku malas membaca yang didominasi oleh para remaja baik yang duduk di bangku sekolah maupun remaja putus sekolah. Kebanyakan dari mereka lebih memilih untuk bermain games dan social media di Smartphone / Gadget, nongkrong atau jalan-jalan yang tidak berguna bersama temanteman, menonton siaran TV dirumah daripada membaca buku. Yang mengakibatkan minat membaca remaja saat ini sangatlah rendah.

Kurangnya kegemaran membaca di kalangan remaja juga terjadi karena remaja telah diberikan informasi secara instan yang biasa diperoleh dari siaran TV dan media elektronik lainnya. Di samping itu, para remaja saat ini menganggap membaca merupakan hal yang membosankan. Padahal dengan membaca kita bisa memperluas kemampuan pengetahuan kita, yang membuat kita untuk lebih tanggap terhadap lingkungan sekitar kita.

Berbagai usaha ke arah peningkatan minat membaca, sekarang telah adanya Gerakan Literasi Nasional (GLN), yang telah dimulai sejak tahun 2016 oleh Kementerian Pendidikan dan Kebudayaan sebagai bagian dari implementasi dari Peraturan Menteri Pendidikan dan Kebudayaan Nomor 23 Tahun 2015 tentang Penumbuhan Budi Pekerti. GLN lahir dari sinkronisasi semua program literasi yang sudah berjalan pada setiap unit utama yang ada di dalam Kementerian Pendidikan dan Kebudayaan, sebagai upaya untuk mensinergikan semua potensi serta memperluas keterlibatan publik dalam pengembangan budaya literasi. Dimensi dari GLN ini yaitu Literasi Numerasi, Literasi Numerasi, Literasi Sains, Literasi Digital, Literasi Finansial, Literasi Baca dan Tulis, serta Literasi Budaya dan Kewarganegaraan. (Kebudayaan, 2017 : 1-7).

Melalui berbagai bentuk kegiatan dalam meningkatkan minat membaca, salah satu diantaranya yaitu diadakan pembentukan Taman Bacaan Masyarakat (TBM), program ini merupakan program nasional dalam rangka mewujudkan masyarakat gemar membaca. Salah satunya TBM yang didirikan di desa Giriasih, TBM ini memerlukan pengembangan dan pemanfaatan oleh masyarakat, khususnya remaja. Hal ini menarik untuk diteliti, dengan menggunakan pendekatan dari Pendidikan Luar Sekolah oleh Pendidikan Masyarakat. 
Dari permasalahan di atas, maka permasalahan yang ingin diteliti oleh peneliti yaitu : (1) Bagaimana pengetahuan remaja tentang keberadaan TBM ?, (2) Bagaimana minat dan pemanfaatan TBM oleh remaja sebagai pusat media pembelajaran ? (3) Kendala-kendala apa saja yang dihadapi oleh para remaja selama membaca di TBM ?

Sedangkan tujuan dari dilakukannya penelitian ini, yaitu : (1) Untuk mengetahui sampai mana pengetahuan remaja tentang keberadaan TBM. (2) Untuk mendeskripsikan minat dan pemanfaatan TBM oleh remaja sebagai pusat media pembelajaran. (3) Untuk mengetahui kendala-kendala apa saja yang dihadapi oleh para remaja hingga saat ini.

\section{LANDASAN TEORI}

\section{Taman Bacaan Masyarakat (TBM).}

TBM mulai dikenal sejak 1950, dengan nama Taman Pustaka Rakyat (TPR), kemudian berganti nama menjadi Taman Bacaan Masyarakat (TBM) pada tahun 1992/1993. Dengan bertujuan untuk mewujudkan masyarakat yang gemar membaca. Menurut Rahayu (2018 : 65), TBM Taman Baca Masyarakat adalah sarana atau tempat yang di dalamnya menyediakan bahan bacaan yang dibutuhkan masyarakat secara umum baik anak-anak remaja sampai usia lanjut dan dikelola oleh masyarakat untuk mewadahi minat baca.

Sedangkan menurut Arsyad (2016: 23), TBM adalah sebuah lembaga atau unit layanan berbagai kebutuhan bagi seseorang maupun sekelompok masyarakat di desa tempat taman bacaan masyarakat berada dalam rangka meningkatkan minat baca dan mewujudkan masyarakat yang berbudaya membaca. Sedangkan menurut Sutarno dalam Arsyad (2017 : 23) menyebutkan bahwa Taman Bacaan Masyarakat mempunyai tanggung jawab, wewenang, dan hak masyarakat setempat dalam membangunnya, mengelola dan mengembangkannya.Dalam hal ini perlu dikembangkan rasa untuk ikut memiliki (sense of belonging), ikut bertanggung jawab (sense of responsibility) dan ikut memelihara.

\section{Minat Baca.}

Membaca merupakan salah satu dari empat keterampilan berbahasa, yaitu keterampilan menyimak / mendengarkan (listening skills), keterampilan berbicara (speaking skills), keterampilan membaca (reading skills), dan keterampilan menulis (writing skills). Sedangkan membaca menurut Hodgson dalam Tarigan (2015 : 7), adalah suatu proses yang dilakukan serta dipergunakan oleh pembaca untuk memperoleh pesan, yang hendak disampaikan oleh penulis melalui media kata-kata / bahasa tulis. Sedangkan dari segi linguistik, membaca adalah suatu proses penyandian kembali dan pembacaan sandi, berlainan dengan berbicara dan menulis yang justru melibatkan penyandian.

Menurut Nurhadi (2015:2), membaca dalam arti sempit adalah kegiatan memahami makna yang terdapat dalam tulisan. Sedangkan dalam arti luas, membaca adalah proses pengelolaan bacaan secara kritis-kreatif yang dilakukan pembaca untuk memperoleh pemahaman menyeluruh tentang bacaan itu, yang diikuti oleh penilaian terhadap keadaan, nilai, fungsi, dan dampak bacaan tersebut.

\section{Remaja.}

Istilah adolescence atau remaja berasal dari kata latin (adolescere) yang berarti tumbuh atau tumbuh menjadi dewasa, memiliki kematangan secara mental, emosional, sosial, dan 
fisik. Sedangkan menurut Piaget dalam (Hurlock, 1999 : 206) menyebutkan bahwa Secara psikologis, masa remaja adalah usia dimana individu berintegrasi dengan masyarakat dewasa, usia di mana anak tidak lagi merasa di bawah tingkat orang-orang yang lebih tua melainkan berada pada tingkatan yang sama, sekurang-kurangnya dalam masalah hak integrasi dalam masyarakat (dewasa) mempunyai banyak aspek afektif, kurang lebih berhubungan dengan masa puber, termasuk juga perubahan intelektual yang mencolok, transformasi intelektual yang khas dari cara berpikir remaja ini memungkinkannya untuk mencapai integrasi dalam hubungan sosial orang dewasa, yang kenyataannya merupakan ciri khas yang umum dari periode perkembangan ini.

\section{Belajar.}

Belajar merupakan perubahan tingkah laku, kemampuan, dan keterampilan yang disebabkan oleh adanya pengalaman dan latihan khusus yang dilakukan oleh seseorang atau individu. Jadi, jika seseorang mengalami perubahan tingkah laku setelah dia mengalami suatu pengalaman, dapat diartikan bahwa orang tersebut telah mengalami belajar.

Menurut Cronbach dalam Jufri (2017 : 49), menyatakan bahwa leaning is shown by a change in behavior as a result of experiments (Belajar ditunjukan oleh adanya perubahan tingkah laku sebagai hasil dari pengalaman dalam proses belajar). Sedangkan menurut Geoch dalam Jufri (2017 : 49), merupakan leaning is a change in performance as a result of practice (Belajar adalah kemampuan dan keterampilan sebagai hasil dari praktik yang dilakukan oleh seseorang). Berdasarkan dua pengertian di atas, belajar merupakan perubahan tingkah laku, kemampuan, dan keterampilan sebagai hasil dari pengalaman dan hasil praktik yang dilakukan oleh seseorang.

Sedangkan, belajar menurut Syah (2013 : 68) merupakan tahapan perubahan seluruh tingkah laku individu yang relatif menetap sebagai hasil dari pengalaman dan interaksi dengan lingkungan yang melibatkan proses kognitif.

\section{METODE PENELITIAN}

Pendekatan yang digunakan adalah pendekatan kualitatif, dengan menggunakan metode Deskriptif. Menurut pendapat dalam Setiaji (2016). Pendekatan kualitatif yaitu pendekatan dengan cara memandang objek penelitian sebagai suatu sistem, artinya objek kajian dilihat dari satuan yang terdiri dari unsur yang saling terkait dan mendeskripsikan fenomena-fenomena yang ada. Sedangkan Metode Deskriptif adalah Metode yang mendeskripsikan atau menggambarkan suatu fenomena atau gejala yang dihubungkan dengan teori-teori yang relevan dengan teori yang digunakan pada variabel penelitian (Darmadi, 2014:186).

Perbedaan Populasi dengan Sampel. Populasi adalah jumlah keseluruhan dari satuan satuan atau individu-individu yang karakteristik nya hendak diteliti, dan satuan-satuan tersebut dinamakan unit analisis, yang dapat berupa orang-orang, institusi-institusi, benda-benda, fenomena alam, dan sebagainya. Sedangkan Sampel adalah sebagian dari jumlah objek / subjek penelitian yang akan diteliti. (Darmadi, 2014: 55-57). Sasaran atau sumber data yang dipakai dalam penelitian ini adalah Pengelola berjumlah 1 orang, Pemilik TBM Gunung Ilmu berjumlah 1 orang, serta pengunjung remaja dari TBM Gunung Ilmu berjumlah 3 orang. Jadi, totalnya 5 orang sampel yang dipakai dalam penelitian ini.

Teknik Sampling yang digunakan yaitu Purposive Sampling. Teknik ini adalah teknik pengambilan sampel dari sumber data dengan pertimbangan tertentu. (Sugiyono, 2015: 
218). Sedangkan untuk instrumen penelitian yang digunakan untuk mengumpulkan data sebagai berikut :

Pertama, Observasi adalah "Salah satu teknik pengumpulan fakta/data yang cukup efektif untuk mempelajari suatu sistem, juga dapat dikatakan sebagai pengamatan langsung para pembuat keputusan atau pengamatan yang dilakukan secara langsung tentang suatu kegiatan tersebut" (Darmadi, 2014:200).

Kedua, Studi Kepustakaan adalah "Suatu uraian atau deskripsi tentang literatur yang relevan dengan bidang atau topik tertentu yang sedang dikaji, berupa buku-buku dan peraturan-peraturan yang ada" (Darmadi, 2014:90).

Ketiga, Wawancara adalah "proses percakapan yang berbentuk tanya jawab antara 2 orang atau lebih yang berlangsung antara narasumber dengan pewawancara. dengan cara tatap muka (Darmadi, 2014:198).

Sedangkan Teknik analisis data yang dipakai yaitu menurut Miles and Huberman dalam Sugiyono (2015) bahwa aktivitas dalam analisis data kualitatif dilakukan secara interaktif dan berlangsung secara terus-menerus sampai tuntas, sehingga data nya sudah jenuh. Langkah-langkah yang di gunakan nya, antara lain :

Pertama, Reduksi data (Data Reduction).Reduksi data yaitu merangkum, memilih hal-hal yang pokok, memfokuskan pada hal-hal yang penting, dicari tema dan pola nya, dengan memberikan gambaran yang lebih jelas, serta mempermudah peneliti untuk melakukan pengumpulan data selanjutnya, dan mencarinya bila membutuhkannya (Sugiyono, 2015 : 247).

Kedua, Penyajian data (Data Display). Penyajian data bisa dalam bentuk uraian singkat, bagan, hubungan antar kategori, flowchart dan sejenisnya, maka data haruslah terorganisasikan, tersusun dalam pola hubungan tertentu, sehingga akan semakin mudah dalam memahami data tersebut (Sugiyono, 2015 : 249).

Ketiga, Kesimpulan dan Verifikasi. Kesimpulan awal yang dikemukakan masih bersifat sementara, dan akan berubah bila tidak ditemukan bukti-bukti yang kuat yang mendukung pada tahap pengumpulan data berikutnya. Tetapi, apabila kesimpulan awal didukung oleh bukti-bukti yang valid dan konsisten saat peneliti kembali ke lapangan mengumpulkan data, maka kesimpulan yang dikemukakan merupakan kesimpulan yang kredibel (Sugiyono, 2015 : 252).

\section{HASIL DAN PEMBAHASAN}

\section{Hasil}

Pertama, pada awal di didirikannya TBM ini, remaja masih belum berkeinginan untuk datang ke TBM karena mereka belum mengetahui apa itu TBM. Namun, sekarang remaja yang datang sudah meningkat, karena mereka sudah mengerti dan sudah mendapatkan manfaat dengan datang ke TBM. Ke dua, saat ini remaja telah memanfaatkan TBM ini selain untuk melakukan beberapa kegiatan selain melakukan kegiatan membaca dan sharing ilmu, mereka dapat melakukan browsing internet karena telah tersedianya fasilitas Wifi di TBM, mereka juga sering datang untuk mengikuti beberapa kegiatan yang diadakan oleh pengelola seperti kegiatan penyuluhan , dan sebagainya. Ke tiga, kendala yang sering dihadapi oleh remaja salah satunya yaitu masih optimal nya promosi yang 
dilakukan pengelola dalam mengajak mereka agar mau datang dan mengikuti kegiatan yang ada di TBM.

\section{Pembahasan}

Pada awalnya, kegiatan dalam meningkatkan minat baca di TBM ini merupakan program dari pemerintahan Kabupaten Bandung Barat, agar meningkatnya minat baca di masyarakat, khususnya di kalangan remaja. Karena remaja akhir-akhir ini lebih banyak bermain Sosmed dan online games daripada membaca buku, apalagi untuk membaca buku di Perpustakaan atau TBM. Setelah itu, dari masing-masing wilayah dengan cara yang berbeda-beda, tetapi untuk di daerah Giri Asih, pejabat pemerintahan akan menginstruksikan kepada masing-masing pemuda yang aktif di lingkungan masyarakat sekitar dengan bekerja sama dengan pengelola TBM Gunung Ilmu, agar memberitahukan program ini kepada remaja yang kurang aktif di masyarakat, untuk datang ke TBM.

Selain kegiatan membaca, dan sharing ilmu, ada pula di adakan berbagai kegiatan penyuluhan yang nantinya berguna bagi remaja. Meski awal pendirian masih belum banyak orang yang tahu akan keberadaan TBM ini, tapi setelah diadakan program ini, makin banyak remaja yang tahu akan keberadaan TBM ini, dan mengikuti kegiatan yang diadakan oleh TBM.

Pemanfaatan yang dilakukan oleh remaja, yaitu dijadikannya tempat bagi mereka untuk bertukar pikiran, dijadikan, tempat berkumpul bila ingin mengadakan kegiatan kemasyarakatan, seperti kegiatan penyuluhan, kegiatan Bazar amal, kegiatan agustusan, dan kegiatan kemasyarakatan lainnya.

Kendala yang dihadapi pengelola sampai saat ini adalah promosi yang belum optimal dilakukan oleh pengelola, kadang dalam mengajak remaja untuk mengikuti kegiatan, dan mereka memilih untuk tidak mengikuti kegiatan yang diadakan, dengan kegiatan mereka masing-masing seperti bermain gadget / sosmed, jalan-jalan yang tidak penting bersama teman sebaya, atau ber gosip tentang orang lain.

\section{KESIMPULAN}

Masih kurangnya minat remaja untuk membaca buku, apalagi untuk datang ke perpustakaan atau TBM sekitar rumahnya, mereka lebih mementingkan bermain online games, sosmed di gadget mereka, nongkrong di kafe bersama teman sebaya yang tidak memiliki tujuan kegiatan yang jelas. Promosi yang belum optimal dilakukan oleh pengelola dalam mengajak remaja untuk mengikuti kegiatan mereka.

\section{DAFTAR ISI}

Arsyad, I. G. (2016). Minat Baca Pengunjung Taman Baca Masyarakat (Studi Pada Kafe Baca BP PAUD \& Dikmas Sulawesi Selatan). Skripsi. Makassar : Universitas Negeri Makassar.

Budimanali. (2019). UNESCO : minat baca Indonesia Cuma 0,001 persen, ini sebabnya. [online]. https://www.kaskus.co.id/thread/586b09af54c07a306e8b4567/unesco-minat-baca-indonesia-cuma-0001-persen-ini-sebabnya/. (diakses 13 April 2019). 
Darmadi, H. 2014. Metode Penelitian Pendidikan dan Sosial (Teori Konsep Dasar dan Implementasi). Bandung: CV Alfabeta.

Hurlock, Elizabeth B. Alih bahasa Istiwidayanti dan Sudjarwo. (1999). Psikologi Perkembangan Edisi Kelima. Jakarta : Erlangga.

Jufri, W. (2017). Belajar dan Pembelajaran Sains : Metode Dasar Menjadi Guru Profesional. Bandung : Pustaka Reka Cipta.

Kebudayaan, K. P. (2018). Panduan Gerakan Literasi Nasional. [Online]. http://gln.kemdikbud.go.id/glnsite/wp-content/uploads/2017/08/panduangln.pdf. (diakses pada 27 Desember 2018).

Nurhadi. Teknik Membaca. (2016). Jakarta : Bumi Aksara.

Rahayu, R dan Widiastuti, N. (2018). Upaya Pengelolaan Taman Bacaan Masyarakat dalam memperkuat minat membaca (studi kasus TBM Silayung Desa Ciburuy Kecamatan Padalarang). Journal of Comm-edu. Vol 1(2) Mei 2018, 57-65.

Setiaji, M. (2016). UPAYA TAMAN BACAAN MASYARAKAT PANGERAN DIPONEGORO DALAM MENINGKATKAN MINAT BACA DI DUSUN SEMBEGO, MAGUWOHARJO, SLEMAN YOGYAKARTA. Jurnal Elektronik Mahasiswa Pend. Luar Sekolah-S1, 5(2).

Sugiyono. (2015). Memahami Penelitian Kualitatif. Bandung : CV Alfabeta.

Syah, M. (2013). Psikologi Belajar. Depok : Rajawali Pers.

Tarigan, H. G. Membaca Sebagai Suatu Keterampilan Berbahasa. (2015). Bandung : CV Angkasa. 